\title{
Managing the Introduction of Circular Products: Evidence from the Beverage Industry
}

\author{
Andrea Urbinati ${ }^{1,2, *}$, Davide Chiaroni ${ }^{2}\left(\mathbb{D}\right.$ and Giovanni Toletti ${ }^{2}$ \\ 1 School of Industrial Engineering, LIUC Università Cattaneo, Corso Matteotti, 22, \\ 21053 Castellanza (VA), Italy \\ 2 School of Management, Politecnico di Milano, Via R. Lambruschini, 4/b, 20156 Milano (MI), Italy \\ * Correspondence: aurbinati@liuc.it
}

Received: 3 June 2019; Accepted: 30 June 2019; Published: 3 July 2019

\begin{abstract}
The aim of this paper is to study what managerial practices companies follow and implement in their business model to manage the introduction of Circular Products. Extensively screening extant literature in the field, we clustered a set of relevant managerial practices in four main principles of Circular Economy (CE) adoption at the product level: (i) Energy efficiency and usage of renewable sources of energy; (ii) Product and process optimisation for resource efficiency; (iii) Product design for circularity; (iv) Exploitation of waste as a resource. Then, the adoption of these principles was tested on two companies (and three Circular Products) operating in the beverage-packaging industry, where the adoption of $\mathrm{CE}$ is further challenged by the fact that packaging is necessary to deliver the product to consumers, but the majority of the one-way packaging is discarded after use. The identified principles provide general objectives in terms of end goals that should be achieved in order to adopt $\mathrm{CE}$ and manage the introduction of Circular Products. This paper shows a practical implementation of these principles on real empirical cases for theory-testing scopes.
\end{abstract}

Keywords: Circular Economy; business models; product; product design; Circular Products

\section{Introduction}

Circular Economy (CE) represents a new industrial paradigm aiming at overcoming traditional systems of production and resources consumption, by encompassing some sustainability approaches, such as regenerative design, performance economy, cradle-to-cradle $(\mathrm{C} 2 \mathrm{C})$, industrial ecology, biomimicry, cleaner production, blue economy, and circular products $[1,2]$. CE is a concrete model that can be also applied in several sectors of activity, such as the use of green energy [3], waste as resources [4], or the modification of industrial processes [5].

Scholars and practitioners in this field are still struggling with how to put CE into practice. Research still falls short in deepening the role of the managerial practices that companies should adopt to design a circular business model, or to reconfigure a traditional one, to reach goals of value creation, cost reduction, revenue generation, and increased resiliency and legitimacy [6-9].

In particular, the set of managerial practices that companies should adopt to implement the CE paradigm and to define circular business models still deserves attention [10,11]. A circular business model can be defined as the way an organisation creates, delivers and captures value with and within closed material loops and chains [12]. In a circular business model, products should become fully reused or recycled, indeed becoming "Circular Products". According to Lewandowski [13], Circular Products have a value proposition characterised by longer product life cycles, higher services that can also be virtualised, collaborative consumption and the incentives and benefits offered to the customers for eventually bringing back used products. 
The aim of this paper is to study what managerial practices companies follow and implement in their business model to manage the introduction of Circular Products. To achieve this aim, this paper relies on a multiple cases analysis [14,15]. In particular, the empirical investigation refers to two companies (and three Circular Products) operating in the beverage-packaging industry.

This sector is particularly interesting from the perspective of CE [16], and especially because the frequency of purchases and high volumes of sales associated with consumer products translate into a large amount of packaging. In particular, it is estimated that each year 207 million tons of plastic (with a value of 384 billion \$) is used globally for packaging. In 2014, approximately 39.5\% of the European plastic demand was related to packaging. The problem is that the majority of this "one-way" packaging is discarded after use. In the European context, clear targets (i.e., recycling 75\% of packaging waste) to reduce waste and foster the adoption of circular business models have been set by authorities. Therefore, there is great potential for "closing the loop" in such a sector. Also, the decision to select the beverage-packaging industry has been taken due to the pervasive attitude of the industry towards reducing the use of raw materials, promoting cost efficiency and looking for innovative environmentally-friendly solutions.

This paper is structured as follows. Section 2 presents the literature review describing the state-of-the-art managerial practices for introducing Circular Products in companies' existing business models. Section 3 highlights the methodology. Section 4 briefly presents the selected cases and further discusses the results of the empirical analysis. Finally, Section 5 points out the concluding remarks and offers suggestions for further research.

\section{Literature Review}

According to the definition by the Ellen MacArthur Foundation [17], Circular Economy (CE) represents an industrial economy that is restorative or regenerative by intention and design. $\mathrm{CE}$ aims at maximising what is already in use along all the phases of the product life cycle. CE can be described as a cycle in which companies, after having harvested resources from the environment and transformed them into products and services, recover them after the consumption. In other words, CE is the cycle of extraction and transformation of resources and the distribution, use and recovery of goods and materials $[6,18]$. In this sense, the real breakthrough of $C E$ is the attention paid to the re-use and recovery in all the phases of the product life cycle and the attempt to avoid the disposal and waste of products [18]. The main difference between CE and the other sustainable paradigms is that the basic idea with the former is not only efficiency, doing more with less, but its recuperative nature $[19,20]$. Therefore, CE can help in mitigating the risks related to higher prices for resources and the higher volatility of resources' markets.

Across the several levels of analysis along which CE can be studied, i.e., the macro- (e.g., policies and regulations), meso- (e.g., eco-industrial parks and clusters), and micro- (e.g., companies' business model and Circular Products) levels, scholars are still struggling to deepen the managerial practices that companies follow and implement in their existing business models to introduce Circular Products. Therefore, in this paper, we tackle the products as a unit of analysis and explore the main managerial practices of $C E$ that companies follow and implement in their business model to manage these products.

As far as the products are concerned, existing research points to the "Design for X" practices and the efficient use of resources. As for the "Design for X" practices, existing research points to Design for Recycling (DfR), Design for Remanufacturing and Reuse (DfRe), Design for Disassembly (DfD) and Design for Environment (DfE) [9,21]. All these practices are required if companies aim to support the end-of-life of products and circular products [22,23]. In addition, the DfE practice refers to the continuous use and improvement of virgin (raw) materials, realising products that could be safer for all the players along the value chain, as well as for humans and the environment [24,25]. In this way, the implementation of these practices is aimed to support the biological and technical cycles of materials (i.e., materials return safely to the environment and without contaminating the biosphere) [23]. 
Research also suggests that, in order to enable the transition towards CE, a re-design of the processes of companies operating along the supply chain is required [26]. The re-design of processes should include the reconfiguration of the supply chains, the implementation of new techniques or production systems and the development of new competences [22,27]. Also, Life Cycle Assessment (LCA) techniques can be useful to determine the effectiveness of material efficiency to reduce emissions [28,29]. In addition to the Design for $\mathrm{X}$ practices for products and processes, $\mathrm{CE}$ is also a model for the efficient use of resources in order to reduce emissions and the environmental footprint $[9,30]$. Finally, as resource and energy efficiency are becoming key sources of new wealth, the transition towards CE gains more importance [31,32]. Indeed, being circular also means reducing energy waste and, hence, exploiting renewable energies. When designing their business model, companies should look at preserving all the resources, including energy and fuel, according to the main goal of CE (i.e., closing loops in as many areas of consumption and production as possible) [28,33]. Most recent studies [34] propose Resource Efficiency Measures (REMs) or practices that companies can implement at the supply side (i.e., supply chain, internal processes, and cost structure), at the demand side (i.e., value proposition, customer interface, and revenue streams), and throughout the life cycle (i.e., use and waste phase of products), to reduce the resources needed for their goods or services.

Another point raised in the literature concerns the upgradability of products through the adoption of a CE approach. Research distinguishes between functional and parametric upgrading [35]. Functional upgrading refers to adding or removing product functions (such as adding the two-sided copying function to a photocopier), whereas parametric upgrading refers to changing the performance of products (such as increasing copying speed). Although upgrading products surely impacts on the value proposition towards customers, its first aim is to address sustainable consumption and production [36].

A final important topic when dealing with the management of waste is discussed in the "Design Out Waste" literature. As underlined by Esposito, et al. [33], "Design Out Waste" means that when products are realised according to the appropriate biological and technical materials cycle, waste should not exist. Indeed, technical materials should be designed to be used several times and with a lower consumption of energy, and biological materials should be nontoxic and environmentally friendly. "Design Out Waste" is a practice that should embrace all kinds of waste [37], i.e., wasted resources (such as fuel), products with wasted life cycle (such as smartphones), products with wasted capability (such as cars) and wasted embedded products (such as textiles that are not reused).

For the purpose of the research, we clustered the above managerial practices into four main principles of CE adoption at the product level, as shown in Table 1.

Table 1. Managerial practices for the introduction of Circular Products.

\begin{tabular}{|c|c|}
\hline Principles & Managerial Practices \\
\hline $\begin{array}{l}\text { 1. Energy efficiency and usage of renewable } \\
\text { sources of energy }\end{array}$ & $\begin{array}{l}\text { - Continuous use and improvement of virgin } \\
\text { (raw) materials (i.e., DfE) }\end{array}$ \\
\hline $\begin{array}{l}\text { 2. Product and process optimisation for } \\
\text { resource efficiency }\end{array}$ & $\begin{array}{l}\text { Resource Efficiency Measures (REMs) or } \\
\text { practices at supply side, demand side and life } \\
\text { cycle to reduce the resources needed for goods } \\
\text { or services } \\
\text { - } \quad \text { Re-design of processes } \\
\text { - } \quad \text { Life Cycle Assessment (LCA) techniques }\end{array}$ \\
\hline Product design for circularity & $\begin{array}{l}\text { Design for X practices (i.e., Design for Recycling } \\
\text { (DfR), Design for Remanufacturing and Reuse } \\
\text { (DfRe), Design for Disassembly (DfD) and } \\
\text { Design for Environment (DfE)) } \\
\text { - Upgradability of products }\end{array}$ \\
\hline 4. Exploitation of waste as a resource & - $\quad$ Design Out Waste \\
\hline
\end{tabular}




\section{Research Methodology: Multiple Cases Analysis}

The empirical research has been based on multiple case studies [14,15]. Case studies are rich, empirical descriptions of particular circumstances of a phenomenon that are typically based on a variety of data sources [15]. This approach is more appropriate to address complex organisational, managerial, and other business issues, which are difficult to study with quantitative methodologies [38]. The qualitative approach carried out allows higher flexibility in design and applications of knowledge and it is consequently more suitable for shaping the complexities of a multidiscipline phenomenon like Circular Economy (CE). Indeed, qualitative research is focused on finding out true inner meanings and new insights that allow the researcher to achieve an elaborate understanding of phenomena [39].

The selection of cases studies has undergone a strict process in order to increase the level of representativeness for the studied phenomenon. First, only "traditional" firms in the beverage industry were considered, in order to have the possibility to truly analyse the transition from a linear to a circular model. Then, among them, we approached only those who have claimed in the last 15 years to have launched Circular Products, having therefore CE as part of their strategy. Two specific companies, Company A and Company B, are the result of this selection. Two idiosyncratic products from Company A and one from Company B were selected: Product A1, an innovative and eco-friendly pricking system, which is based on a polyethylene terephthalate (PET) recyclable keg; Product A2, a bottle made from natural sources, cellulose and wood fibres, with low carbon content and that is totally recoverable; Product B1, a 100\% biodegradable bottle totally composed of BIO PLA, which is a special biopolymer that is generated by natural sources without using petrol.

To collect empirical evidence for our cases, we chose personal direct semi-structured interviews with key informants. In particular, interviewing key informants is a primary source of data to gather multiple views on the same subject and reduce potential personal bias. As part of these interviews, a semi-structured questionnaire, consisting of open-ended questions, has been used as a guide for the collection of all the empirical data [40]. It allowed collecting different points of view during the interviews, thereby increasing the richness and reliability of the findings [14]. The interviews were conducted between May 2018 and September 2018 by the research team. They typically lasted between 60 and 90 min each. In addition, data gathered from interviews were triangulated and integrated through the analysis of secondary sources, such as annual reports, sustainability reports, and companies' websites.

Table 2 presents the cases synopsis. 
Table 2. Cases synopsis.

\section{Company A}

Since 2002, Company A, is the Italian unit of a Danish group, which is one of the major players in the brewing industry. Today, Company A has a turnover of over $€ 120$ million and employs approximately 350 people. With over 1,300,000 hL of beer produced every year, Company A is the third major beer producer in the world. The firm's portfolio has a wide geographical scope thanks to the high variety of controlled brands and the customers are divided into two categories: (i) large-scale distribution (GDO) and Special clients; (ii) Hotels, Restaurants, and Cafès (Ho.Re.Ca.).Company A believes in the CE approach both for economic and environmental reasons and, according to the literature suggestions, has developed a Circular Community, with several providers (cans, glass bottle coatings, glass packaging, shrink-wraps, paperboard multipacks, and polyethylene terephthalate (PET) kegs for draught beer).

\section{Product A1}

Product A1 is an innovative and eco-friendly pricking system, which is based on a single-use PET recyclable keg. It also uses a pioneering way of dispensing draught beer, connected to the existing beer lines, beer cooler and beer tap. The pricking procedure is as follows:

- Compressed air is pumped into the pressure chamber. The system works without the internal emission of $\mathrm{CO}_{2}$ within the keg, instead using external air compression (by not adding $\mathrm{CO}_{2}$, costs are reduced, maintenance costs decrease and there is also an improvement in beer quality);

- The keg is squeezed, and fresh beer is pressed out. Freshness is increased from 7 days maximum for steel kegs to a minimum of 31 days;

- Beer is pushed through the tap to create the perfect beer. Flexible,

semi-automatic line cleaning and one-way kegs keep things fresh and simple.

Although the first idea and the technology of the project were born in the laboratory of the group's headquarters, the development and launch of the project were almost immediately moved to Company $\mathrm{A}$, which has taken the responsibility to develop and realise the product and to sell it all over the world. The development and introduction of Product A1 on the market has required several years from the first launch of the project in 2007, through the introduction of several versions on the market, until 2017 when $92 \%$ of Company A's beer was distributed via PET kegs. The new Product A1 system has achieved several results: (i) $\mathrm{CO}_{2}$ elimination; (ii) highe beer quality and durability; (iii) simpler, cheaper and more environmentally-friendly sanitisation; (iv) simpler disposal of the PET keg that can be easily recycled. In addition, the development of the system has required a close collaboration of Company A with its suppliers and a continuous interaction with its customers.

\section{Product A2}

Product A2 can be considered an excellent example of successfully rethinking beverage packaging. It is made entirely from natural materials (cellulose-wood fibres), hence with low carbon content, and is totally recoverable. Furthermore, even in cases when the bottle is not recycled and ends up in nature, it will decompose without harming the environment. The raw materials are basically trees, and the aim is to extract the fibres from forests managed in a proper way (i.e., trees are replanted at the same rate at which they are harvested). Product A2 is being developed by Company A and its Circular Community. The first prototype was presented in January 2015 by the Chairman of Company A's foundation at the World Economic Forum and production started soon after. Company A decided to invest in this project for several reasons. On the one hand, as a matter of fact, reducing the environmental impact of its products is one of the pillars of its mission. On the other hand, Company A also wants to reduce the problem of "branded" waste that can damage its reputation. Despite the best efforts to recycle waste, plenty of them escape from the recycling system and much of them end up in the oceans, causing huge negative impacts on the environment and damaging the brand. 
Table 2. Cont.

Company B

Company B is one of the major players in the beverage industry of water and soft drinks. It was founded in 1996 and, today, Company B's water, with its low mineral content, is esteemed and drunk worldwide and it generates a turnover of almost $€ 280$ million and a volume of sales of 1.3 billion of litres. Company B, after having strengthened its leadership in the mineral water market, decided to diversify its portfolio in 2012, entering into the soft drinks industry.Company B's culture and its strategy are strongly

oriented to the respect of both planet and people. These values are a direct consequence of a strong bond with nature and can be summarised with this statement: "Water is our origin. The origin of water is nature". Sustainability, quality, technology, innovation and focus on the product are the key words of Company B. Company B has always been characterised by a sustainable mindset and it is strongly oriented to the protection and respect of the environment. Such behaviour can be seen at different levels. The plant has been built according to eco-friendly principles, using raw materials such as wood and stones and exploiting the heat produced by the plant for heating the offices. Outbound logistics is based on the railway system with trains departing every day from the plant. All the handling at the plant's warehouse is managed by electric laser-guided robots to avoid pollution. New robot wrappers were introduced to reduce plastic use in the final packaging. Several other initiatives to reduce the environmental impact are under way.

\section{Product B1}

The product that best represents the "new" circular approach of Company B is Product B1. Product B1 is a 100\% biodegradable bottle that was launched in 2008. The product was a pioneer, being the first launched in the global mass market and, even today, it is still the only compostable bottle present in Italy. It was the first bottle in the world made entirely of BIO PLA, a special biopolymer that derives from natural sources without using petrol. Thanks to this inherent characteristic, the bottle respects the environment in all the steps of its life cycle. Indeed, it is produced from a natural and renewable source and it can be disposed in the organic waste since it is compostable in less than 80 days, according to the regulation EN13432. Consequently, Product B1 is 100\% biodegradable and it can be used by consumers without leaving a trace in the environment. Company B has started in 2008 a revolution in the world of packaging that has not been yet surpassed nor even equalled. The breakthrough was the development of an eco-friendly package that protects the inherent water's characteristics and, at the same time, respects the environment. In recent years, the direct competitors of the company are still strongly focused on plastic and are struggling to gradually reduce the quantity of plastic in each bottle. 


\section{Results and Discussion}

Starting from the analysis of the case studies presented above, this section highlights how the managerial practices of Circular Economy (CE) have been followed and implemented by Company A and Company B in their business model to manage their products (Table 3).

Both the analysed companies adopted a "resource recovery" business model. It leverages on technological innovations and capabilities to recover and reuse resource outputs, to eliminate material leakage, and to maximise economic value since waste materials are re-processed into new resources. Also, the empirical analysis shows that both Company A and Company B deploy the circular paradigm by adopting principles of $\mathrm{CE}$ in their internal activities and relationships with suppliers, customers and other relevant stakeholders. In some cases, also revising their value proposition.

The cross-analysis of the three product-based case studies has allowed us to reflect on how the CE principles drawn from the theory (see Table 1) are implemented in practice and with which benefits (see Table 3). The first evidence of the empirical analysis is that not all the theoretical principles of CE and related managerial practices depicted in Table 1 above are always fully applied for each product. Becoming circular for a company is not an overnight transformation, but it is a business model transition, for which there is always a continuous space for improvement [41-43]. In addition, it appears that some principles seem to be easier to scale out than others.

Principle 1. Energy efficiency and usage of renewable sources of energy.

The evidence for this principle is not really clear cut. Indeed, both the analysed companies focus more on energy efficiency than on the usage of renewables sources of energy. All the three studied products, indeed, were designed in order to reduce energy consumption during the production process. Exploiting renewable sources of energy however has not been an issue.

Circular products should be designed in order to use materials characterised by fewer emissions and energy consumption, but it is also important to design the production process itself in order to increase its energy efficiency [24,25]. Exploiting renewable sources of energy could not be a priority in the first phases of the product life cycle, but it is something to be considered once the product and the production process begin to consolidate.

Principle 2. Product and process optimisation for resource efficiency.

All the circular products that have been analysed follow this principle. Indeed, all the companies' business models focus on the willingness to use resources more efficiently and to reduce as much as possible every type of waste [28,29].

In particular, we may mention the case of Product B1. Here, the importance of efficiency has been really understood only after the first, partially successful, launch, due to the high cost of the product. Hence, Company B became aware of the fact that, in order to reduce the final price of the product, the only possibility was to reduce the cost. In turn, such reduction could have been achieved only by increasing the efficiency of the production process. In particular, Company B wanted to develop an efficient production process, minimising waste and inefficiency. Today, the production site of the company is internationally recognised as one of the most technologically advanced and, within the plant, there are eighteen entirely automated lines. The efficiency of the automation systems has been exploited by the company also for the packaging phase and for internal logistics. It has greatly reduced the amount of plastic used. 
Table 3. The introduction of Circular Products in the studied companies.

\begin{tabular}{|c|c|c|c|c|}
\hline Products & $\begin{array}{c}\text { Principle 1 } \\
\text { Energy Efficiency and Usage of } \\
\text { Renewable Sources of Energy }\end{array}$ & $\begin{array}{c}\text { Principle 2 } \\
\text { Product and Process Optimisation for } \\
\text { Resource Efficiency }\end{array}$ & $\begin{array}{c}\text { Principle } 3 \\
\text { Product Design for Circularity }\end{array}$ & $\begin{array}{c}\text { Principle } 4 \\
\text { Exploitation of Waste as a Resource }\end{array}$ \\
\hline Product A1 & $\begin{array}{l}\text { Usage of PET kegs that have } \\
\text { fewer emissions and energy } \\
\text { consumption than the } \\
\text { traditional supply cycle with } \\
\text { steel kegs. }\end{array}$ & $\begin{array}{l}\text { The product's performances are } \\
\text { continuously measured in order to } \\
\text { improve them. Moreover, the product } \\
\text { was designed with the inherent } \\
\text { mentality of continuous improvement } \\
\text { since it is developed to overcome the } \\
\text { main shortcomings of steel keg. }\end{array}$ & $\begin{array}{l}\text { The product was designed to underpin } \\
\text { the circular design pillars of "reduce" in } \\
\text { order to use less impactful packaging } \\
\text { materials, and "recycle" to increase the } \\
\text { recycled content of packaging materials. } \\
\text { The interaction among the product's } \\
\text { components is studied to guarantee that } \\
\text { those who decide to use the new system } \\
\text { do not have to change the entire pricking } \\
\text { system. Moreover, since the product can } \\
\text { be recycled, the idea is that there are } \\
\text { precise cascade processes defined. }\end{array}$ & $\begin{array}{l}\text { Using PET as the principal raw material } \\
\text { of kegs allows the deployment of more } \\
\text { simple recycled techniques and } \\
\text { therefore reduces the difficulties in } \\
\text { waste management activities. }\end{array}$ \\
\hline Product A2 & $\begin{array}{l}\text { To increase the energy efficiency } \\
\text { of the production process, the } \\
\text { thermoforming technique has } \\
\text { been chosen. It consists of } \\
\text { injecting and drying the fibre } \\
\text { under high pressure. }\end{array}$ & $\begin{array}{l}\text { The main challenges are how to deal } \\
\text { with liquid content and the energy } \\
\text { required for the bottle's production. } \\
\text { However, both product and process } \\
\text { characteristics are optimised thanks to } \\
\text { the collaboration with several } \\
\text { stakeholders. }\end{array}$ & $\begin{array}{l}\text { The product was presented by the } \\
\text { company as the best example for the } \\
\text { successful rethinking of beverage } \\
\text { packaging. Indeed, with this product, } \\
\text { beer packaging is totally revised. } \\
\text { Given that the raw materials for this } \\
\text { product are basically trees, if the bottle } \\
\text { ends up in nature, it will decompose } \\
\text { without harming the environment. In } \\
\text { this way, the company has developed a } \\
\text { natural cascade process for the product. }\end{array}$ & $\begin{array}{l}\text { The product is designed with a } \\
\text { biodegradable fail-safe mechanism. In } \\
\text { this way, it is possible to find new life } \\
\text { for waste thanks to the focus on } \\
\text { biomaterials that are able to return to } \\
\text { the source, not as waste but as a } \\
\text { resource. }\end{array}$ \\
\hline Product B1 & $\begin{array}{l}\text { The product leads to a } 60 \% \\
\text { reduction of energy in the } \\
\text { plant's manufacturing process. }\end{array}$ & $\begin{array}{l}\text { The main efforts of the company are } \\
\text { dedicated to making the product } \\
\text { economically sustainable-in particular, } \\
\text { through the optimisation of the } \\
\text { production process and thanks to an } \\
\text { effective communication and marketing } \\
\text { strategy. }\end{array}$ & $\begin{array}{l}\text { The product was developed according to } \\
\text { the circular design principle. Indeed, it is } \\
\text { obtained from a natural and renewable } \\
\text { source and it can be disposed in the } \\
\text { organic waste since it is compostable. } \\
\text { The company developed a product with a } \\
\text { natural cascade process. Indeed, it comes } \\
\text { from a natural and renewable source; it } \\
\text { returns to the environment without } \\
\text { leaving a trace in less than three months } \\
\text { and it does not contain petroleum or its } \\
\text { by-products. }\end{array}$ & $\begin{array}{l}\text { The product is designed with a } \\
\text { biodegradable fail-safe mechanism. In } \\
\text { this way, it is possible to find new life } \\
\text { for waste thanks to the focus on } \\
\text { biomaterials that are able to return to } \\
\text { the source, not as waste but as a } \\
\text { resource. }\end{array}$ \\
\hline
\end{tabular}


Product and process optimisation for resource efficiency is a widely diffused principle since it is closely related to the increasing scarcity of resources, which is one of the main trends that fosters the adoption of the CE paradigm [31,32]. Moreover, the economic availability of resources and the efficiency of processes represent today critical success factors for businesses. In each case, a lot of efforts and investments are dedicated to find both new alternative resources as well as production processes that can lead to efficiency results. As previously mentioned, optimisation practices to obtain efficient processes are a key concept both for academics and practitioners [22,26,27].

Principle 3. Product design for circularity.

As with the previous one, this principle has also been followed in all the studied cases. Especially for what concerns the comprehensive evaluation of interactions between components, which mostly implies paying attention to the upgradability of products $[35,44]$ and to the design of both the upstream and the downstream phases of the process $[9,13,45]$.

In particular, the importance of designing products in a cascade way, by looking at all the possible interactions among components, is an important pillar for Company A that developed Product A2, which is one of the best examples of successful design of beverage packaging. Indeed, this innovative product is based on the idea of being able to enter a recycling cascade before returning to the source, not as waste but as a resource $[10,11]$. The launch of this project has been guided mainly by two reasons. First, Company A totally bases its business on natural resources that will be likely jeopardised in the future. Second, the problem of branded waste could become a big issue in terms of reputation for the company that will be likely penalised by the presence of its products in the natural plastic landfill.

It is important that companies design products and components that can enter in a loop and be completely recycled. A fundamental step is optimising the design of products and components in order to allow the reduction of recycling costs, maintaining at the same time a high quality and all the functionalities of the product. The principle of "Product design for circularity" also means that products are created by considering all the possible flows and optimising the recovery of all the goods' components.

Principle 4. Exploitation of waste as a resource.

Both Company A and Company B invested a lot to realise products with sustainable and biodegradable materials to facilitate recycling and reduce the difficulties in waste management activities [33,37]. This is particularly true for products A2 and B1 that were designed with a biodegradable fail-safe mechanism, allowing for recovering waste through the use of biomaterials.

Circular Products should be designed having in mind the idea to transform waste into resources. "Waste" should be no longer be a problem, but a source of new value for the same supply chain or for other supply chains $[18,46,47]$.

\section{Conclusions}

This paper was aimed to study the managerial practices that companies follow and implement in their business model to manage the introduction of Circular Products.

First, this paper has analysed the literature identifying a set of relevant managerial practices for Circular Economy (CE) adoption at the product level. Then, it has clustered them into four main principles of $\mathrm{CE}$ adoption at the product level, i.e., (i) Energy efficiency and the usage of renewable sources of energy, (ii) Product and process optimisation for resource efficiency (iii) Product design for circularity, and (iv) Exploitation of waste as a resource. After that, this paper showed a practical implementation of these principles on real empirical cases for theory-testing scopes.

Although the analysed companies seem to demonstrate the validity and reliability of the principles of CE adoption at the product level, interesting issues remain to be deepened in future research. First, although the identified principles provide general objectives in terms of end goals that should be achieved in order to adopt CE and manage the introduction of Circular Products, they however do not 
clarify at what level each principle should be fulfilled to transform an economy into full circularity. Some emerging questions that remain unanswered are: (i) Should a company only use $100 \%$ of renewable energy to be fully circular? (ii) What is the level of acceptable waste generated in a CE? (iii) Should all the principles be fulfilled to state that an economy is circular? These questions highlight, on the one hand, a set of challenges to put the concept into practice and, on the other hand, the need to find a new way to justify the implementation of the circular paradigm over time to increase the degree of circularity of companies' business model.

In addition, it could be interesting to deeply examine the barriers that hamper the managerial practices for CE adoption at the product level, that, only in part, can be studied starting from the analysed cases. Among these barriers, those that deserve attention by future scholars are: (i) Technological limitations, i.e., circular deployment may require specific technologies (e.g., recycling technologies) and processes (e.g., product design); (ii) Lack of government support, i.e., absence of the right encouragement through the provision of funding opportunities and effective taxation policy as well as the complexity of regulation; (iii) Economic barriers, i.e., difficulties in defining a suitable business structure for adopting the $\mathrm{CE}$ approach, in which costs and revenues are balanced; (iv) Change in mindset, i.e., a reluctance to acknowledge that the current way of producing and consuming cannot proceed further and unwillingness to shift to a more long-term perspective; (v) Financial barriers, i.e., the cost of green innovation and business models; (vi) Lack of information, i.e., the lack of knowledge about the benefits of the circular economy; (vii) Lack of support from the supply and demand network, i.e., lack of suppliers' and customers' environmental awareness; (viii) Leadership: i.e., the company's leader appreciates the new strategic direction, understands its benefits, but also its risks, and is able to establish a common understanding in the business; (ix) Motivation, i.e., the concept of CE implies that being sustainable, and at the same time profitable, is possible and it also pushes creativity and improves moral culture; $(\mathrm{x})$ Customer behaviour, i.e., end users are more environmentally friendly and hence the demand of eco-friendly products increases. In this way, end users are putting more pressure on businesses to adopt more environmentally cautious practices.

Among the main limitations of this paper, we underline those typically characterising qualitative studies, such as the lack of generalisability of findings, the lack of quantitative methodology to support the study, as well as the limited number of the sampled cases.

Author Contributions: A.U. depicted the theoretical setting and the research design, D.C. depicted the conceptualisation of the paper and revised the final version, G.T. wrote the first draft, including the empirical analysis, and revised the final version.

Funding: This research received no external funding.

Conflicts of Interest: The authors declare no conflict of interest.

\section{References}

1. Cordova-Pizarro, D.; Aguilar-Barajas, I.; Romero, D.; Rodriguez, C.A. Circular economy in the electronic products sector: Material flow analysis and economic impact of cellphone e-waste in Mexico. Sustainability 2019, 11, 1361. [CrossRef]

2. Fonseca, L.; Domingues, J.; Pereira, M.; Martins, F.; Zimon, D. Assessment of circular economy within Portuguese organizations. Sustainability 2018, 10, 2521. [CrossRef]

3. D'Adamo, I. The Profitability of Residential Photovoltaic Systems. A New Scheme of Subsidies Based on the Price of $\mathrm{CO}_{2}$ in a Developed PV Market. Soc. Sci. 2018, 7, 148. [CrossRef]

4. Rosa, P.; Sassanelli, C.; Terzi, S. Circular Business Models versus Circular Benefits: An Assessment in the Waste from Electrical and Electronic Equipments Sector. J. Clean. Prod. 2019, 231, 940-952. [CrossRef]

5. Ghisellini, P.; Cialani, C.; Ulgiati, S. A review on circular economy: The expected transition to a balanced interplay of environmental and economic systems. J. Clean. Prod. 2016, 114, 11-32. [CrossRef]

6. Park, J.; Sarkis, J.; Wu, Z. Creating integrated business and environmental value within the context of China's circular economy and ecological modernization. J. Clean. Prod. 2010, 18, 1494-1501. [CrossRef] 
7. Tukker, A. Product services for a resource-efficient and circular economy-A review. J. Clean. Prod. 2015, 97, 76-91. [CrossRef]

8. Manninen, K.; Koskela, S.; Antikainen, R.; Bocken, N.; Dahlbo, H.; Aminoff, A. Do circular economy business models capture intended environmental value propositions? J. Clean. Prod. 2018, 171, 413-422. [CrossRef]

9. Urbinati, A.; Chiaroni, D.; Chiesa, V. Towards a new taxonomy of circular economy business models. J. Clean. Prod. 2017, 168, 487-498. [CrossRef]

10. Ünal, E.; Urbinati, A.; Chiaroni, D. Managerial practices for designing circular economy business models: The case of an Italian SME in the office supply industry. J. Manuf. Technol. Manag. 2019, 30, 561-589. [CrossRef]

11. Ünal, E.; Urbinati, A.; Chiaroni, D.; Manzini, R. Value Creation in Circular Business Models: The case of a US small medium enterprise in the building sector. Resour. Conserv. Recycl. 2019, 146, 291-307. [CrossRef]

12. Roos, G. Business model innovation to create and capture resource value in future circular material chains. Resources 2014, 3, 248-274. [CrossRef]

13. Lewandowski, M. Designing the business models for circular economy-Towards the conceptual framework. Sustainability 2016, 8, 43. [CrossRef]

14. Eisenhardt, K.M. Building theories from case study research. Acad. Manag. Rev. 1989, 14, 532-550. [CrossRef]

15. Yin, R.K. Case Study Research and Applications: Design and Methods; Sage publications: Thousand Oaks, CA, USA, 2017.

16. Ronzon, T.; M'Barek, R. Socioeconomic Indicators to Monitor the EU's Bioeconomy in Transition. Sustainability 2018, 10, 1745. [CrossRef]

17. Ellen MacArthur Foundation. Toward the Circular Economy Vol. 1: Economic and Business Rationale for an Accelerated Transaction; Ellen MacArthur Foundation: Cowes, UK, 2012.

18. Stahel, W.R. The circular economy. Nat. News 2016, 531, 435. [CrossRef] [PubMed]

19. Geissdoerfer, M.; Savaget, P.; Bocken, N.M.; Hultink, E.J. The Circular Economy-A new sustainability paradigm? J. Clean. Prod. 2017, 143, 757-768. [CrossRef]

20. Kirchherr, J.; Reike, D.; Hekkert, M. Conceptualizing the circular economy: An analysis of 114 definitions. Resour. Conserv. Recycl. 2017, 127, 221-232. [CrossRef]

21. Marconi, M.; Germani, M.; Mandolini, M.; Favi, C. Applying data mining technique to disassembly sequence planning: A method to assess effective disassembly time of industrial products. Int. J. Prod. Res. 2019, 57, 599-623. [CrossRef]

22. Mendoza, J.M.F.; Sharmina, M.; Gallego-Schmid, A.; Heyes, G.; Azapagic, A. Integrating Backcasting and Eco-Design for the Circular Economy: The BECE Framework. J. Ind. Ecol. 2017, 21, 526-544. [CrossRef]

23. Moreno, M.; Court, R.; Wright, M.; Charnley, F. Opportunities for redistributed manufacturing and digital intelligence as enablers of a circular economy. Int. J. Sustain. Eng. 2018, 1-18, 77-94. [CrossRef]

24. Smieja, J.M.; Babcock, K.E. The intersection of green chemistry and Steelcase's path to circular economy. Green Chem. Lett. Rev. 2017, 10, 331-335. [CrossRef]

25. Niero, M.; Hauschild, M.Z. Closing the loop for packaging: Finding a framework to operationalize Circular Economy strategies. Procedia CIRP 2017, 61, 685-690. [CrossRef]

26. Galati, A.; Schifani, G.; Crescimanno, M.; Vrontis, D.; Migliore, G. Innovation strategies geared toward the circular economy: A case study of the organic olive-oil industry. Riv. Di Studi Sulla Sosten. 2018, 2018, 137-158. [CrossRef]

27. Palm, H.W.; Knaus, U.; Appelbaum, S.; Goddek, S.; Strauch, S.M.; Vermeulen, T.; Haïssam Jijakli, M.; Kotzen, B. Towards commercial aquaponics: A review of systems, designs, scales and nomenclature. Aquac. Int. 2018, 26, 813-842. [CrossRef]

28. Gilbert, P.; Wilson, P.; Walsh, C.; Hodgson, P. The role of material efficiency to reduce CO2 emissions during ship manufacture: A life cycle approach. Mar. Policy 2017, 75, 227-237. [CrossRef]

29. Scheepens, A.E.; Vogtländer, J.G.; Brezet, J.C. Two life cycle assessment (LCA) based methods to analyse and design complex (regional) circular economy systems. Case: Making water tourism more sustainable. J. Clean. Prod. 2016, 114, 257-268. [CrossRef]

30. Frenken, K. Political economies and environmental futures for the sharing economy. Philos. Trans. R. Soc. A Math. Phys. Eng. Sci. 2017, 375, 20160367. [CrossRef]

31. Esposito, M.; Tse, T.; Soufani, K. Is the circular economy a new fast-expanding market? Thunderbird Int. Bus. Rev. 2017, 59, 9-14. [CrossRef] 
32. Parajuly, K.; Wenzel, H. Potential for circular economy in household WEEE management. J. Clean. Prod. 2017, 151, 272-285. [CrossRef]

33. Esposito, M.; Tse, T.; Soufani, K. Introducing a circular economy: New thinking with new managerial and policy implications. Calif. Manag. Rev. 2018, 60, 5-19. [CrossRef]

34. Lopez, F.J.D.; Bastein, T.; Tukker, A. Business model innovation for resource-efficiency, circularity and cleaner production: What 143 cases tell us. Ecol. Econ. 2019, 155, 20-35. [CrossRef]

35. Umeda, Y.; Daimon, T.; Kondoh, S. Life cycle option selection based on the difference of value and physical lifetimes. In Proceedings of the International Conference on Engineering Design (ICED'07), Paris, France, 28-31 July 2007; pp. 1-12.

36. Pialot, O.; Millet, D.; Bisiaux, J. "Upgradable PSS": Clarifying a new concept of sustainable consumption/production based on upgradability. J. Clean. Prod. 2017, 141, 538-550. [CrossRef]

37. Lacy, P.; Rutqvist, J. Waste to Wealth: The Circular Economy Advantage; Springer: Berlin/Heidelberg, Germany, 2015.

38. Ghauri, P.N.; Grønhaug, K. Research methods in business studies: A practical guide. Pearson Education.

39. Zikmund, W.G.; Babin, B.J.; Carr, J.C.; Griffin, M. Business Research Methods; Cengage Learning: Boston, MA, USA, 2018.

40. Eriksson, P.; Kovalainen, A. Qualitative Research in Business Studies; Emerald Group Publishing Limited: Bulgari, UK, 2001.

41. de Mattos, C.; de Albuquerque, T. Enabling Factors and Strategies for the Transition Toward a Circular Economy (CE). Sustainability 2018, 10, 4628. [CrossRef]

42. Merli, R.; Preziosi, M. The EMAS impasse: Factors influencing Italian organizations to withdraw or renew the registration. J. Clean. Prod. 2018, 172, 4532-4543. [CrossRef]

43. Bermejo, R. Circular economy: Materials scarcity, European union policy and foundations of a circular economy. In Handbook for a Sustainable Economy; Springer: Dordrecht, The Netherlands, 2014; pp. 269-287.

44. Mugge, R. Product Design and Consumer Behaviour in a Circular Economy. Sustainability 2018, $10,3704$. [CrossRef]

45. Bocken, N.M.; de Pauw, I.; Bakker, C.; van der Grinten, B. Product design and business model strategies for a circular economy. J. Ind. Prod. Eng. 2016, 33, 308-320. [CrossRef]

46. Malinauskaite, J.; Jouhara, H.; Czajczyńska, D.; Stanchev, P.; Katsou, E.; Rostkowski, P.; Thorne, R.J.; Colon, J.; Ponsa, S.; Al-Mansour, F.; et al. Municipal solid waste management and waste-to-energy in the context of a circular economy and energy recycling in Europe. Energy 2017, 141, 2013-2044. [CrossRef]

47. Perey, R.; Benn, S.; Agarwal, R.; Edwards, M. The place of waste: Changing business value for the circular economy. Bus. Strategy Environ. 2018, 27, 631-642. [CrossRef] 